\title{
—交献 紹介心
}

1. 応用力学・機㧔力学

2. 工業材料. 材料学

3. 测定機・測定洗

4. 䓡. 䓡力学

5. 燃料・撚焼

6. 蒸気発生装置

7. 蒸氕原動機・復水器
8. 内燃機関

9. 航空機・航空発動機

10. 自動車: 自動車機関

11. 鉄道・鉄道車阿

12. 船舶 - 舶用機関

13. 流体力学 - 水力機䑰

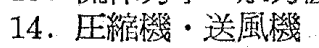

摘 錄 分 類
15. 䁔冷房・冷活
16. 機構・自動制御・機栈 要素
20. 紡織
17. 工作機的 . 工作矤
18. 鋳造・鉎造・プレス・ 溶接
19. 起垂機・運搬機
21. 化学機栈
22. 製造・水座機㭜
23. 土木機战・㖉山機㽣
24. 工場管理・絴浭
25. 工菜敉青
26 . 雑

\section{1. 応用力学およど機械力学}

$621.03: 534.01$

\section{[32] 非線形力学序說}

[N. Minorsky, Introduction to Non-linear Mechnics, J. W. Edwards (1947) 全 464 ページ〕本甾

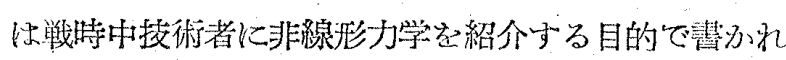

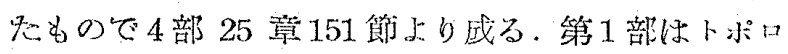
ジカルな方法, 第 2 部《解析的方法，第 3 部《非線形 垬振，第4 部は relaxation uscillation 起論じている。 Andronow-Chaikin, Kriloff-Bogoliuboff, Poincaré, Liapounoff などの所説を技術者に近付きすい形に, しかもかなら体柔的にま乞め上げ手腕はこの著者な

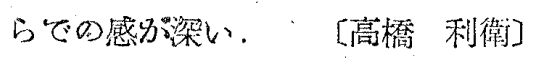

621.03. : 531.3

\section{[33]運動の安定性飞関する一般的諸問題}

〔A. Liapounoff, Problème géééral de la stabilité du mouvement, Annals of Mathematics Studiès No. 17, Princeton Univ. Press (1949) 全474ページ」

Liapounoff の原著は露交で 1892 年に Kharkow て 発表され，1907 年に Annales de la Faculté des Science de Toulouse, Second series, Vol. 9 k Davaux の仏訳が出夫ので步るが，非線形力学が盛心になるに

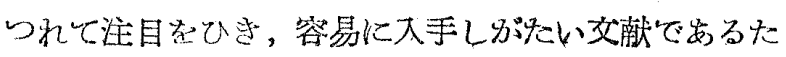
め Princeton で Tourouse 版の複写が出るに至った ので岁る。本書の内容は Poincaré の業蹟と共に斯界 の双璧ともいらべき“新しい”古典でするから紹介の 要は发るまい。【高橋 利衛]

$621.03: 534.01$

\section{[34]振 動 力 学}

[Y. Rocard, Dynamique gérérale des vibrations, Masson \& Cie, (1949) 全439 ページ, 1900 フランJ

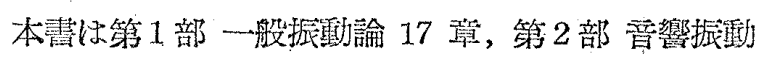

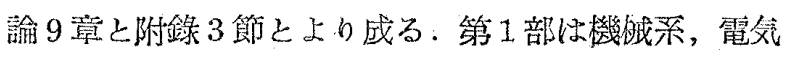
系, 電気一機战系, 物理系などの振動現象を広い視野 そ深い理解の上に與味深く説述している。特に自别振

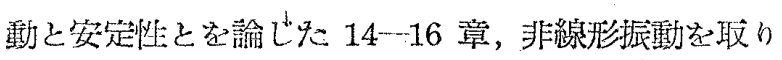

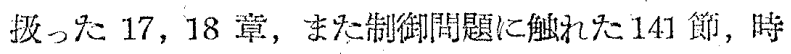

間ょくれ振動を述べを142節などは本青の近代的性格

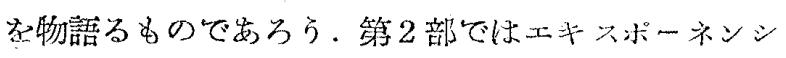
ヤル・ホーン内の有限振幅の曋波志諭じを7章名腿圭。 ひく. ‘[高橋 利衛]

\section{$539.3: 512.97$}

\section{[35] 力学および弾性学に敊けるテン・ル解}

[Leon Brillouin, Les tenseurs en méchanique et en élasticité, Masson \& Cie (1949) 全370 ページ, c00 フラン」本畵は1938 年初版の再版で岁って, 主々 して力学, 弾性学に敌けるテンソル解析の有效性を主 㖘し，その応用起 12 章にわたり論じ太もので女るが， 著者の広い取枋は単に才学, 弹性学の籍困にとど恋ら ず，近代物理学上のトピックスにまで仗んでいるのは

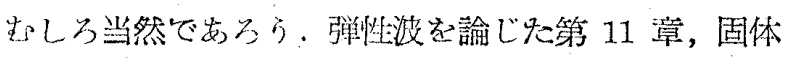

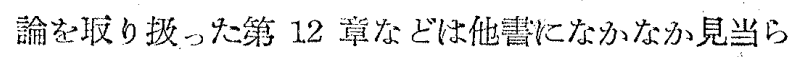

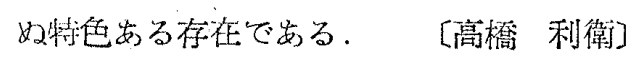
$512.8 / .9$

\section{[36] マ・リックスおよびテンソル}

〔A. D. Michal, Matrix and Tensor Calculus with Applications to Mechanics, Elasticity, and Aeronautics, John Wiley (1948) 全132 ページ]本畫依 著者が 1942 年1月名ら 1943 年 3 月まで標題の内谷 ○戦時敎育 (Engirieering, Science, and Management

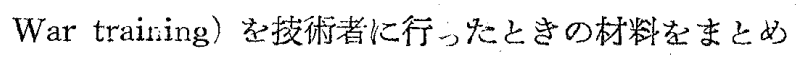
たもので考るから，小冊于のうちに要領上く最大限の

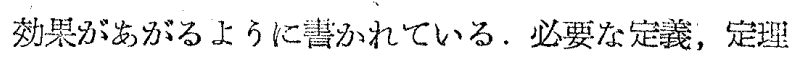
等も笑際閒題の説明に際して導入するというような

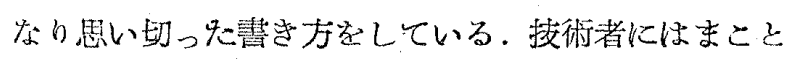
に便利な本で串る。【高橋 利衛】 51.7 .9

\section{[37] 微、分方 程 式}

[S. Lefschetz, Lectures on Differential Equations, Prirceton Univ. Press (1948)全210ページ〕、マ卜 リックス, ベクトル空閪論，多变数の解析多九数論，

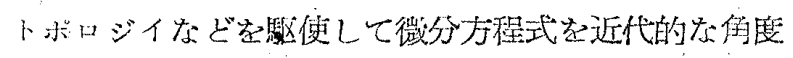

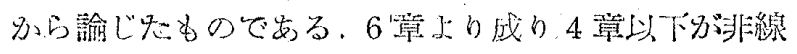

